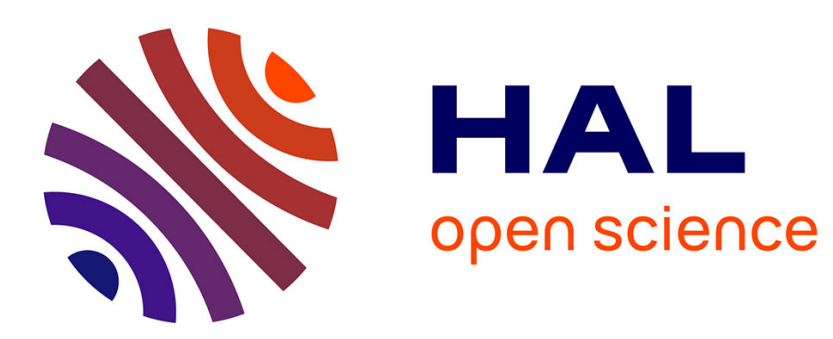

\title{
Double Dividend and Distribution of Welfare: Advanced Results and Empirical Considerations
}

\author{
Mireille Chiroleu-Assouline, Mouez Fodha
}

\section{To cite this version:}

Mireille Chiroleu-Assouline, Mouez Fodha. Double Dividend and Distribution of Welfare: Advanced Results and Empirical Considerations. Économie Internationale, 2010, 2009 (4T / 120), pp.91-108. hal-00519529

\section{HAL Id: hal-00519529 \\ https: / hal-paris1.archives-ouvertes.fr/hal-00519529}

Submitted on 11 Oct 2017

HAL is a multi-disciplinary open access archive for the deposit and dissemination of scientific research documents, whether they are published or not. The documents may come from teaching and research institutions in France or abroad, or from public or private research centers.
L'archive ouverte pluridisciplinaire HAL, est destinée au dépôt et à la diffusion de documents scientifiques de niveau recherche, publiés ou non, émanant des établissements d'enseignement et de recherche français ou étrangers, des laboratoires publics ou privés. 


\title{
Double Dividend and Distribution of Welfare: Advanced Results and Empirical Considerations
}

\author{
Mireille Chiroleu-Assouline" \\ Mouez Fodha
}

Paris School of Economics and Université Paris 1 Panthéon-Sorbonne (Centre d'Economie de la Sorbonne)

\begin{abstract}
The objective of this paper is to analyze the efficiency and equity consequences of the implementation of an environmental tax. Do the two purposes collide or can they be simultaneously achieved? Using results of the related literature, we show that precise conditions have to be met in order to achieve three goals: increase of the environmental quality, increase of the economic efficiency and improvement of the intergenerational equity. Are such theoretical conditions likely to occur? What are the rooms of manoeuvre for an environmental tax reform in the European countries? In each of them, the revenues of the existing environmental taxes are low in comparison to the weight of the labor taxes (which are highly distortionary). Using European data, we show that, among all the European countries, Belgium, France and, surprisingly, Sweden, exhibit the less green tax system and offer the easiest opportunity to use the environmental tax as a mean to alleviate the tax burden on labor.
\end{abstract}

JEL classification: D60 - D62 - E62 - H23.

Keywords: Environmental tax - Heterogenous agents - Welfare analysis - Tax progressivity.

- Corresponding Author. Université Paris 1, Maison des Sciences Economiques, 106-112 Bld de 1'Hôpital, 75647

Paris Cedex 13. E-mail : Mireille.Chiroleu-assouline@univ-paris1.fr. 


\section{1- Introduction}

"A rising price on carbon emissions is the essential underlying support needed to make all other climate policies work. [...] A rising carbon price is essential to "decarbonize" the economy, i.e., to move the nation toward the era beyond fossil fuels. The most effective way to achieve this is a carbon tax (on oil, gas, and coal) at the well-head or port of entry. [...] The public will support the tax if it is returned to them [...]" This warm apology of the carbon tax is not due to an European economist, nor a European politician, but to an American scientist, James Hansen ${ }^{1}$ who became in the United States one of the main advocates of the tax against the cap and trade approach. This quite surprising attitude corresponds to a larger movement in favor of the price instrument because of the relative failure observed until now of the emissions trading system as an instrument for the GHG regulation. In fact, this movement takes place in Europe too, where the Swedish presidency of the European Union (second semester of 2009) encouraged the other member countries to implement carbon taxes bearing on all sectors of activity which are not regulated by the emission quotas system.

As well as the cap and trade mechanism, the tax allows to achieve the environmental objectives while minimizing the global cost. One of the advantages of an environmental tax is that it provides public revenues which can be recycled. This is a reason why it can be preferred to subsidies or emission quotas. It has been argued that, as governments use these revenues to decrease other distortionary taxes, an environmental tax may lead to a double dividend, according to Goulder's definition, by improving the environmental quality and achieving a less distortionary tax system (Goulder [1995]). This can be a strong argument in favor of an increasingly green tax system. But one of its disadvantages is that, like any consumption tax, it often appears to be regressive, i.e. more harmful for the welfare of the poorest households than for the richest ones. What would be the inequality consequences of the European Carbon Tax Project or of the Climate-Energy Contribution planned by the French government as from 2010? Hence, as Hansen suggests it, an environmental tax can hardly be considered without adequate revenue recycling in order to enhance the acceptance of the environmental policy. But the aim of such a recycling can therefore be twofold to reduce, or even annihilate the gross cost of the policy, as

\footnotetext{
${ }^{1}$ Eminent climatologist, he is director of the NASA Goddard Institute of Space Studies. After the election of U.S. President Barak Obama in November 2008, J. Hansen sent him a letter to urge him to support a carbon tax.
} 
measured by the global welfare loss, or to compensate the generated vertical inequity.

The objectives of this paper are to analyze the efficiency and distributional consequences of the implementation of a carbon tax and to enlighten the links between the different purposes of the recycling of its revenue. Do the two purposes collide or can they be simultaneously achieved? What are the rooms of manoeuvre in the European countries? Does the present situation not constitute an opportunity to undertake a tax reform of major scale?

This article suggests some answers to these questions by giving insights of the results in the double dividend theory. We compare the main contributions of the existing literature, focusing on our previous works, and we show that the conditions to obtain a successful environmental tax policy rely on the objectives and constraints of the policy: welfare equity, environmental quality, economic efficiency, and employment... Nevertheless, the Tinbergen rule cannot be set aside and achieving all these goals simultaneously seems very hard and require strong structural conditions to be met. These conditions concern, as usual, specific characteristics of the production functions' elasticities, agents' preferences and initial level of the tax rates. Secondly, in the lights of these theoretical results, this paper gives some empirical considerations in order to determine the opportunities for the European countries to adopt a global environmental tax policy. Using European data, we show that, among all the European countries, Belgium, France and, surprisingly, Sweden, exhibit the less green tax system and offer the easiest opportunity to use the environmental tax as a mean to alleviate the tax burden on labor.

The paper is organized as follows. Section 2 presents the concept of double dividend and studies the conditions of its achievement by the mean of a balanced "green" tax reform. Section 3 emphasizes the distributional effects of an environmental tax between generations, especially when there is involuntary unemployment. Section 4 enlightens the distributional effects between different categories of households and puts forward an appropriate policy mix to compensate them. Section 5 gives some empirical considerations using European data and the last section concludes.

\section{2- In quest of the double dividend: theoretical results insights}

Can an environmental tax reform be designed without negatively affecting the economic welfare? 
This still open question has given rise to a huge literature on the double dividend. Terkla [1984] first had the intuition that the recycling of the revenue of an environmental tax could reduce or even eliminate the gross cost of its implementation. Baumol and Oates [1988], Pearce [1991] and Oates [1991] suggest that these efficiency gains could be a powerful argument in favor of environmental taxation. After some prior refutations of the double dividend hypothesis (Bovenberg and de Mooij [1994] and their followers), Goulder [1995] and Ligthart [1998] show that the existence of the double dividend essentially depends on the possibility of transferring the global tax burden from the wage earners to some fixed production factors or to other consumers, thus emphasizing the role of heterogeneity. Following this line, in Chiroleu-Assouline and Fodha [2005] and [2006], we study the existence conditions of a long term double dividend, taking into account the distinction between wage earners and retired consumers, by means of overlapping generations models.

A necessary condition to obtain a double dividend lies in the Laffer-efficiency ${ }^{2}$ of the initial tax system: the increase in the environmental tax rate has to allow a decrease of the labor tax rate, which is not always and everywhere guaranteed. It depends on the elasticity of each fiscal base to its tax rate and more precisely on the relative sizes of the fiscal base effects and of the tax rate effects. If one of the taxes (labor or environment) would not be Laffer efficient, the double dividend could not be obtained because, instead of reducing the existing tax distortions, the tax reform would enhance them.

Although these theoretical results are obtained in a static framework, conditions to obtain a double dividend are already hard to verify. Nonetheless, as global environmental policies concern the very long term, one cannot neglect the dynamic consequences of these policies. We will see that the take into account of intergenerational considerations, like advocated in the Bruntland's report when defining the sustainable development concept, increases the number of constraints.

\section{Seeking for a third dividend: the long-term dynamic efficiency}

Results concerning the dynamic properties of the double dividend objective can be found in Chiroleu-Assouline-Fodha [2006]. Our analyze of the double-dividend and welfare distribution

\footnotetext{
${ }^{2}$ A tax is Laffer-efficient if its revenue grows when the tax rate increases.
} 
issues takes place within a framework of overlapping generations models which seems more convenient for analyzing such environmental problems. In the absence of altruism, the behaviour of private agents is responsible for an intergenerational environmental externality. The solution which is usually advocated in order to internalize this kind of externality is the implementation of environmental taxation. But such taxes imply non-environmental welfare losses for the generations bearing them. It is the reason why generally the generation which has to implement the reform is the one which mainly bears its costs. The main contribution of Chiroleu-AssoulineFodha [2006] is then to examine, with an appropriate demographic framework, whether a revenue-neutral increase in the pollution tax compensated by a change of the labor tax can yield a double dividend, by (i) achieving the long term environmental objective and (ii) improving the long term non environmental welfare.

More generally, the intertemporal double dividend could be defined as an improvement of the discounted intertemporal social welfare of all generations. It takes into account the welfare of the generations alive during the transition between initial and final steady-states. This welfare criterion leads to the modified golden rule which is preferred to the golden rule criterion because of both ethical and practical problems: the first generations would be sacrificed to the future generations while these ones will fully benefit from the environmental policy; moreover, decisions about future environmental improvements are to be made by present generations which support their economic costs. The arguments given by Goulder and Stavins [2002], for instance, in order to justify discounting apply here to justify the use of the modified golden rule.

Our results about the intertemporal double dividend are then linked to the general discounting debate. Even if some generations are made worse off along the transition path, any increase in the social discount factor rises the weight of the welfare of the infinite number of generations alive in the final steady-state equilibrium and (in case of a long term double dividend) increases the occurrence probability of an intertemporal double dividend. We focus then on the comparison of long term steady state equilibria because a necessary condition to obtain an intertemporal double dividend is that the generations on the new steady state equilibrium are made better off with respect of both environmental and non-environmental welfare. We show that, according to the discounted social welfare criterion, a double dividend can occur.

Nevertheless, the issue of acceptability by the present generations induces us to study the necessary conditions not only for environmental policy to be beneficial in the long term but also 
for not damaging the welfare of the generation which has to take the decision to implement the policy.

In this paper (Chiroleu-Assouline-Fodha [2006]), the economy consists of two periods lived individuals being affected by the quality of the environment during their all life. We assume that overall consumption is polluting. The government is financing its spending with a labor tax and the pollution tax. We study the necessary conditions for environmental policy to be beneficial in the long term and we examine the compatibility conditions of both dividends: these necessary conditions depend on the capital intensity of the initial steady state equilibrium relative to the golden rule. We show that the fiscal change does not always harm the welfare of the present generations and that, under some peculiar assumptions; it is possible to obtain both a long term double dividend and the respect of short term intergenerational equity.

More precisely, the existence conditions of a double dividend rely on the initial per capita capital stock, on the initial tax rates and on the intertemporal elasticity of substitution. Our first conclusion is that, whatever the initial capital intensity of the economy, the double dividend cannot be obtained if the intertemporal elasticity of substitution is equal or greater than unity. Furthermore, if this elasticity is less than unity, the existence of the double dividend depends on the position of the economy relative to the golden rule and to the modified golden rule.

In case of over-accumulation of capital, the double dividend cannot occur. Indeed the consumption of the young generation should increase while the one of the old one should decrease and both taxes should be Laffer-efficient. In this last case, the environmental fiscal reform may be justified from an ecological point of view, when the initial pollution level is greater than the optimal one, but not from an economic point of view as the research of a double dividend gets the economy farther from the social optimum.

In case of under-accumulation of capital, the existence of a double dividend needs a reduction of the consumption of the old generation and an increase of the young one and it can occur only if one of the taxes is Laffer-inefficient and if the initial capital stock is greater than the one defined by the modified golden rule.

The analysis of the distributional effects between younger and older coexisting at a given date shows that the environmental fiscal reform always induces a non-environmental welfare loss for one of the existing generations: the young one when the reform bears ex post on wages, the old one when it bears on capital. For nobody to be harmed, the first dividend needs to be high 
enough.

\section{3- Distributional intergenerational effects in case of involuntary unemployment}

The existing literature before the clarification paper by Goulder [1995] usually considered many kinds of second dividend: rise in employment, improved efficiency, improved distributional equity (the three kinds of dividend distinguished by Ekins [1995]) or rise in private profits, cut in the cost of public funds, and so on. But all these dividends, except the distributional one, are part of the one and only convenient criterion that refers to economic efficiency. Nevertheless, an employment dividend can also be defined, which plays in favour of the efficiency dividend without coinciding with it.

Moreover, beside potential efficiency properties, environmental decisions have an impact on the welfare of both current and future generations, as explained before. These intergenerational issues on environmental externalities or on taxation have been quite widely studied in the economic literature. In an overlapping generations framework, John et al. [1995] examine the effect of an environmental tax whose revenue is financing a public pollution abatement activity. Fisher and van Marrewijk [1998], using an endogenous growth model with pollution, derive the conditions for a pollution tax not to slow economic growth. More generally, the literature on the double dividend issue leads to some clear results (Bosello, Carraro and Galeotti [2001]): when the economy is made of one productive sector, using only one productive factor (labor), and one representative consumer, the strong version of the double dividend is rejected. Instead, when there are several productive factors and/or several consumer groups, the double dividend can be obtained but at the expense of equity (Bovenberg and van der Ploeg [1995], Proost and van Regemorter [1995], Bovenberg and Heijdra [1998]). For instance, Bovenberg and Heijdra [1998] examine the effects of a green tax on polluting capital when the tax revenue is redistributed by lump-sum intergenerational transfers and find that this tax benefits the younger generation but harms the older ones. This property might question the relevance of the fiscal reform if it harms some generations. Nevertheless, any environmental tax is based on the equity and intergenerational solidarity principle: it aims to give to the future generations the same environmental amenities as to the present generations. But such a fiscal reform will only be 
acceptable if it improves the global welfare of all generations, the present like the future ones. All these papers conclude that environmental taxation implies such a welfare loss for older generations that its implementation cannot be wished: one of the generations which would decide it would also bear the heaviest burden.

We study the existence conditions of a double dividend (according to Goulder's definition), but also the role of the employment dividend and the distributional equity issue in ChiroleuAssouline and Fodha [2005]. The distributional concern can be viewed between different classes of households (employed and unemployed) or between different generations.

This paper integrates both the efficiency and intergenerational distributional aspects of environmental taxes. Under the assumption of involuntary unemployment, we examine whether a revenue-neutral increase in the pollution tax compensated by a change of the labor tax can yield a double dividend. This general framework can be related to those of Bovenberg and Heijdra [1998] and Bovenberg and van der Ploeg [1996] but differs from them in several ways. Bovenberg and Heijdra [1998] do not explicitly address the double dividend issue but investigate whether a higher pollution tax can be Pareto welfare improving by benefiting all generations. In their paper, pollution is due to capital utilization while we assume that the fiscal base of the environmental tax is consumption (which causes pollution) rather than capital; their paper focus mainly on optimal capital taxation which allows them to pay little attention to the employment issue. But we show that the existence of unemployment adds another way for obtaining a double dividend. Lastly, we assume that involuntary unemployment is caused by an exogenous minimum wage rate, like Bovenberg and van der Ploeg [1996] (who do not consider more than one generation).

In Chiroleu-Assouline and Fodha [2005], the economy consists of two periods lived individuals working and consuming when young and consuming and being affected by the quality of the environment only when being old. The government is financing its spending (public investment and unemployment benefits) with a labor tax and a pollution tax. We characterize the specification of the fiscal reform when the revenue of the pollution tax is recycled by a variation of the rate of social contributions instead of by lump-sum transfer.

We show that the fiscal change does not always harm the welfare of the younger generation and, 
under certain assumptions about agents' preferences, it is possible to obtain both a double dividend and the respect of intergenerational equity. We show finally that, under some conditions about the variations of the unemployment rate and of the interest rate, an inter-generations distributional dividend can also be obtained. More precisely, the employment dividend is warranted and, under some conditions, a double dividend can be obtained. It depends on the relative magnitude of the effects on the income, on the interest rate and on the fiscal base of the pollution tax. Indeed, if the environmental enforcement of the fiscal system yields a decrease of the labor tax rate, the environmental dividend is more likely to occur but the second and third dividends are less likely to occur that the fall in unemployment and the rise in interest rate are lower.

\section{4- In quest of fairness and acceptability by heterogeneous households}

One of the most publicly debated issues about environmental regulation concerns its effects on the poorest agents and the fairness of such a policy. How could these detrimental consequences be smoothed or even eliminated?

Environmental policies are indeed an issue in which income class plays a significant role. First, the poor and the rich seem to assign different degrees of priority to environmental protection (Baumol and Oates [1988]). This is quite intuitive since assuming environmental quality as a normal good, one would expect that wealthier individuals would want to buy more of it. Second, distributive elements also matter when we consider how the costs of a policy of environmental protection are likely to be distributed among individuals with differing incomes. Since indirect taxes have been proved to be regressive, any environmental tax policy is likely also to be regressive. In particular, in the French case, a tax on energy or transport consumption harms the lowest wage households three times more than the highest wage households (Ruiz and Trannoy [2008]). Moreover, the usual recycling of the environmental tax revenues through a decrease in the labor tax rate could also be regressive (Metcalf [1999]). This second point is of interest in a world in which inequality and poverty have assumed high priority among social issues. In addition, without adequate consideration of this aspect of the matter, it would be hardly possible to design policies that can obtain the support they require for adoption. Thus, by ignoring their 
distributive effects, environmental policies may unintentionally harm certain groups in society. While positive net benefits from environmental policy imply that the gains have exceeded the losses for society as a whole, this may not be true for all members of society. Some segments of society may bear a disproportionate share of costs. Paying attention to environmental justice makes sense for two reasons, one ethical and the other pragmatic. The ethical dimension concerns whether the distribution of benefits and costs is in accordance with the norms of social justice. Desirable policies are both efficient and fair. The pragmatic dimension emphasizes the relationship between the distributional burden and both the likelihood that environmental legislation will pass and its ultimate form. Policies and programs that are perceived as unfair will stand little prospect of passage even if they enhance the prospects for efficiency and sustainability. Identifying the sources of unfairness and restructuring programs to eliminate them increases the likelihood that otherwise desirable programs can proceed.

It is well known that the norms of social justice are not sufficiently well defined such that no norm is beyond reproach. Nonetheless, some conventional approaches have arisen that can serve to guide our inquiry (Atkinson [1983]). These involve two concepts known as horizontal and vertical equity. Horizontal equity occurs when people with equal income are treated equally. With respect to pollution control, the principle of horizontal equity is satisfied if all persons with the same income receive the same net benefit. Vertical equity deals with the treatment of unequal or, using income as a basis, with the treatment of those with different income levels. The first step in assessing whether a particular policy satisfies vertical equity is to calculate how the net benefits are distributed among income groups: progressively, regressively or proportionally. A regressive allocation occurs only if the ratio of net benefit to income is larger for the rich than the poor. Hence, regressive policies violate the vertical equity principle.

We noticed that the large body of literature which has deeply analyzed the double dividend issue has surprisingly neglected the distribution issue of the welfare gain, although it is usually obtained at the expense of some groups of agents. The potential contradiction between efficiency and distributional concern has yet already been emphasized by some works in other frameworks (Bovenberg and van der Ploeg [1995], Proost and van Regemorter [1995], Bovenberg and Heijdra [1998]).

Our most recent paper (Chiroleu-Assouline and Fodha [2009]) intends to fill this peculiar gap and 
to analyze whether an environmental tax policy can respect the two equity principles simultaneously, the vertical as well as the horizontal one. We consider the possibility of designing an environmental policy in order to ensure a non-decreasing welfare for each class of workers. Compared to the standard double dividend literature which pursues two objectives improve the environment by increasing an environmental tax (first dividend) and the economic welfare by decreasing another distortionary tax (second dividend) - we add the third objective of Pareto improvement. It corresponds to an acceptability/unanimity criterion for the policy when agents are heterogeneous. The aim of this paper is therefore to design a balanced environmental tax reform able to correct these regressive properties of taxes and to leave all classes of worker better off.

This paper relies on an overlapping generations model, with polluting capital, but sharing the mean features of Chiroleu-Assouline and Fodha [2005] and [2006].

As in Chao and Peck [2000] or Williams [2002] or [2003], we assume that the degradation of environmental quality has a negative impact on the total productivity of factors. This assumption is justified by the results of an increasing number of empirical studies measuring the health effects of pollution (OECD [2008]) and the impact of the health of workers on labor productivity (Bloom et al. [2004], in a sample consisting of both developing and industrial countries, found that good health, proxied by life expectancy, has a sizable, positive effect on economic growth). Since Ostro [1983], many papers have emphasized the loss of productivity caused by the health effects of pollution, e.g. Samakovlis et al. [2005], or Pervin et al. [2008] for air-pollution, and also Bosello et al. [2006] or Hübler et al. [2008] for the health effects of climate change.

We assume that the production technology is a function of capital and heterogeneous labor. Heterogeneous workers live two periods (young and old) and earn wages corresponding to their skill and consequently to their productivity. The labor tax is a very general one that could be either a progressive or proportional tax. Our demographic assumptions allow us to take into account several income classes; indeed, we consider (i) the heterogeneity characteristics of the labor market (high wages - skilled workers, middle wages, low wages - non skilled workers...), (ii) the heterogeneity of the individual income sources (wages for workers, savings for retirees). The environmental policy consists of increasing the environmental tax on savings, in a secondrank framework. We then characterize the necessary conditions for the obtaining of a double 
dividend, i.e. an improvement of the environmental quality and an improvement of the welfare when the revenue of the pollution tax is recycled by a change in the labor tax rates. Previous studies show that the existence of a double dividend requires economic conditions such that the double dividend hypothesis seems unrealistic. Conversely, we show that the conditions for the double dividend existence lie in the distributive properties of the labor taxes. Even when the double dividend is not possible, the cost of the pollution regulation can be minimized by a new designing of the progressivity of the labor tax instead of an homogenous cut in the labor tax rates. The results are dependent on the initial tax system.

We also emphasize that (i) an increase of the environmental tax deteriorates the welfare of all and is regressive, (ii) the low paid workers prefer an environmental tax reform balanced by a decrease in the flat rate component but the high paid workers prefer a decrease of the progressivity. We conclude that the distributive properties of the tax policy could be one of the instruments of internalization of the intergenerational externalities.

To a certain extent, our paper highlights the gap between economic efficiency and vertical equity and illustrates the problem of the aggregation of positive and negative compensatory variations: the usual method of aggregation gives a higher weight to the wealthiest classes and introduces a bias when assessing the desirability or the acceptability of any environmental tax reform.

\section{5 - In quest of the double dividend: some empirical considerations}

What are the rooms of manoeuvre for the European countries? In each of them, the revenues of the existing environmental taxes are low in comparison to the weight of the social contributions (employees' and employers') and of the income tax (see Figure 1): from 4,6\% for France or Belgium up to $10 \%$ for the Netherlands. Labor taxes are widely thought to be highly distortionary in European countries (EC, 1998 or Fiorito and Padrini, 2001), at the opposite of United States where the tax bearing on capital exerts the highest distortion and was targeted by the first studies addressing the double dividend issue (Goulder, 1995 and Bovenberg, 1999). For example, Scott (2007) finds that the excess burden of labor taxes in European countries (France, Germany, Italy) is about twice than in USA, Canada or Japan (Fig 5, p 939). In line with these findings, Hansson 
(2007) shows that in Sweden the deadweight loss associated with using the existing labor tax rather than a lump-sum tax is in the order of $30 \%$ of its revenue.

Figure 1

Tax Structure in EU15 countries - 2006

Percent of total tax revenues

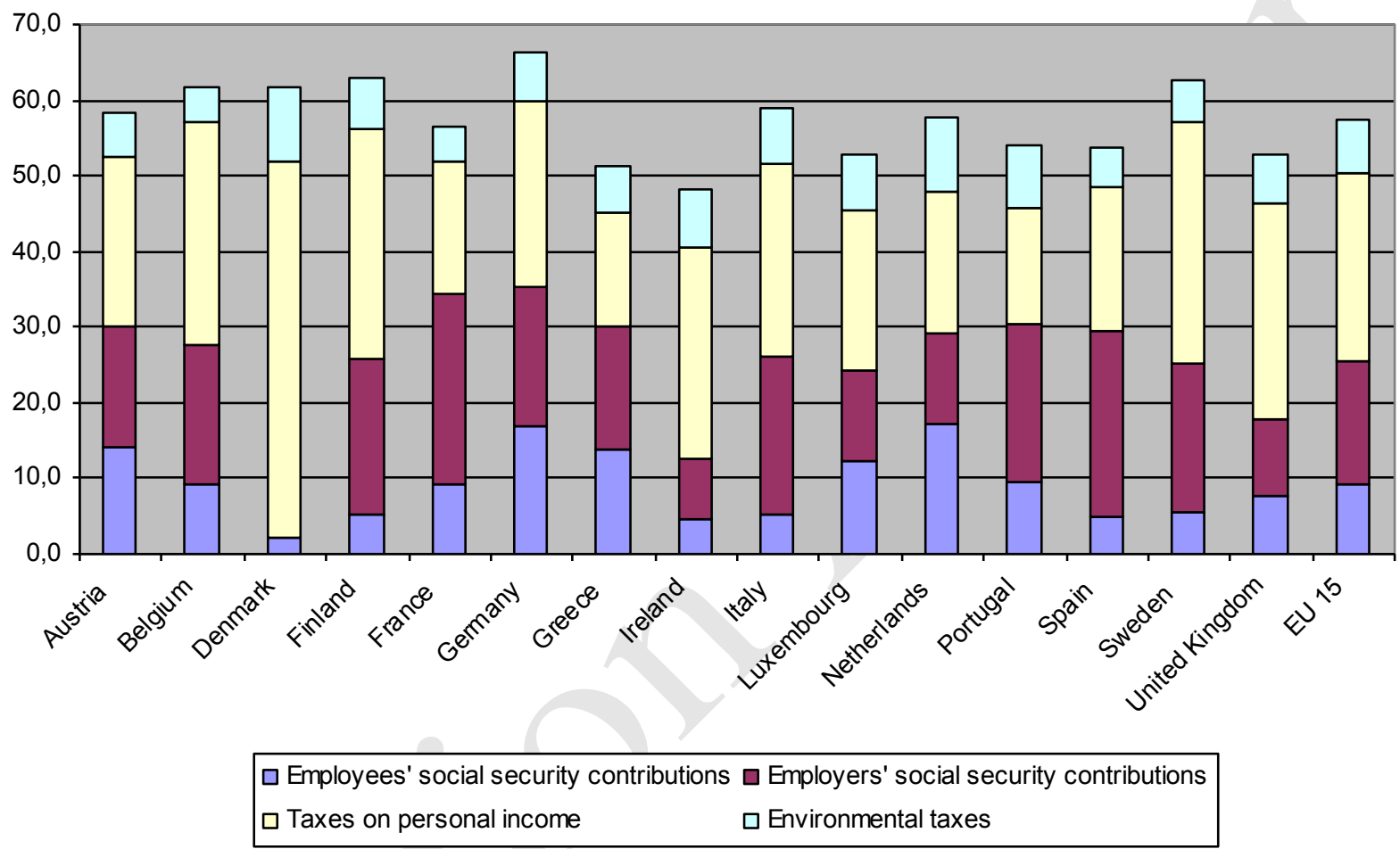

Source : OECD (2008) Revenue Statistics 1965-2007

In order to enlighten the possibilities of greening the tax structure of the European countries, we define the potential transformation ratio of a tax system as the ratio of the revenues of the environmental taxes to the revenues of the other taxes bearing essentially on labor (income tax and social contributions). For EU15, the revenue of the environmental taxes account approximately to $13,5 \%$ of the revenues of labor and personal income taxes. Compared to this mean, among all the European countries, the Netherlands, Ireland and Denmark are characterized by the "greeenest" tax structure (see Figure 2) because they already have transferred a significant part of their fiscal revenues on environmental taxes. At the other side, Belgium, France and, surprisingly, Sweden exhibit the less green tax system and offer the easiest opportunity to use the 
environmental tax as a mean to alleviate the tax burden on labor and to reduce the welfare loss due to the inefficiency of the present tax system.

Figure 2

Potential transformation ratio

Revenues of environmental taxes / revenues of Income tax and Social Contributions Deviations in points of percentage to the mean for EU15 (13,5\%)

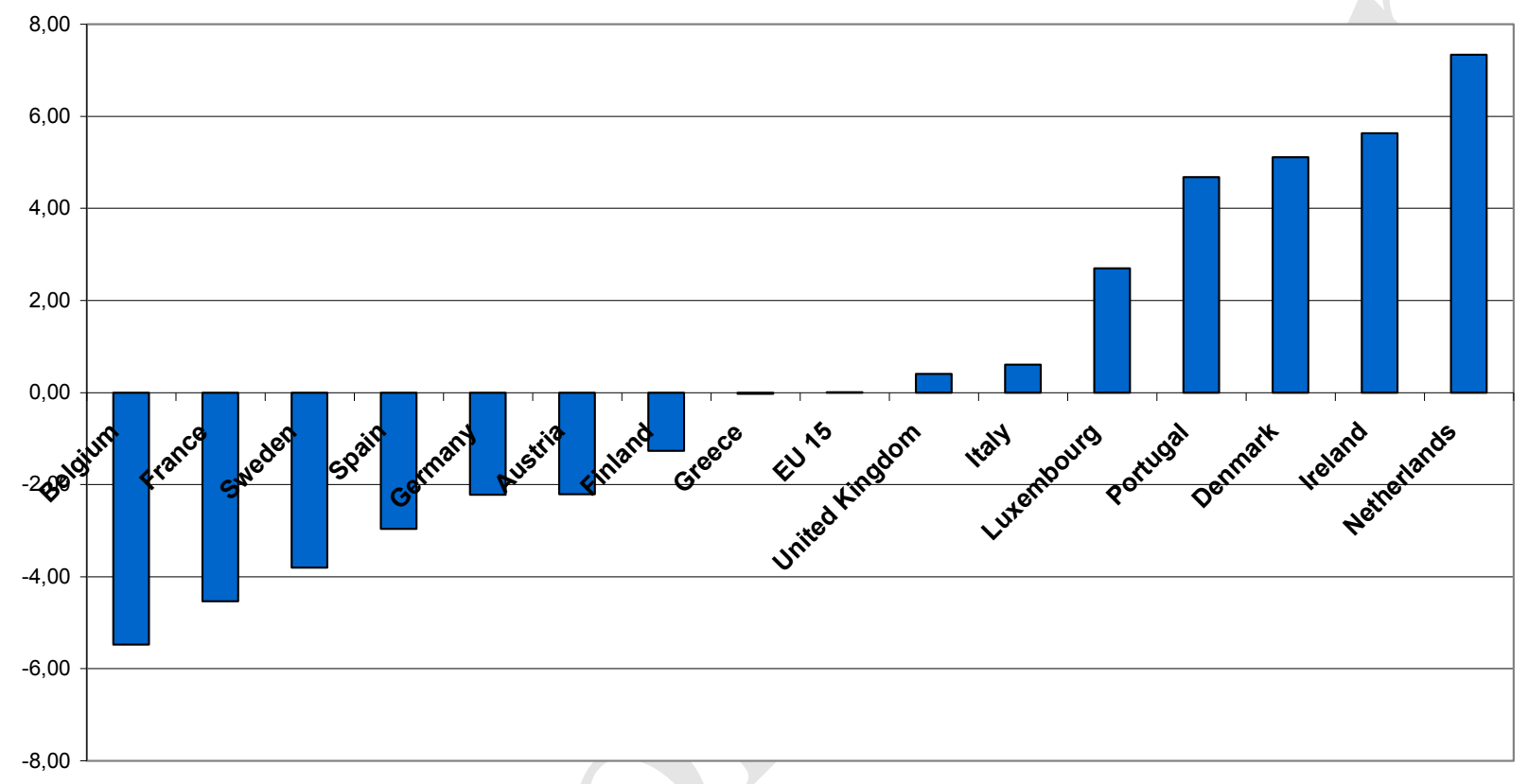

Source : OECD (2008) Revenue Statistics 1965-2007

This indicator reflects only a part of the tax choices of a country since it can be small also because the share of the other taxes (like capital tax or consumption tax) is itself relatively small. To correct from this bias, we normalize the potential transformation ratio by the sum of the shares of all the taxes considered here: income tax, social contributions and environmental taxes. This normalized indicator is graphed in Figure 3, which shows that the ranking between the European countries is not drastically modified by the normalization: the last four countries remain the same, (even the evidence is now less for Sweden) and the four "greenest" countries also. 
Figure 3

Normalized Potential transformation ratio

Deviations in points of percentage to the mean for EU15 (7,7\%)

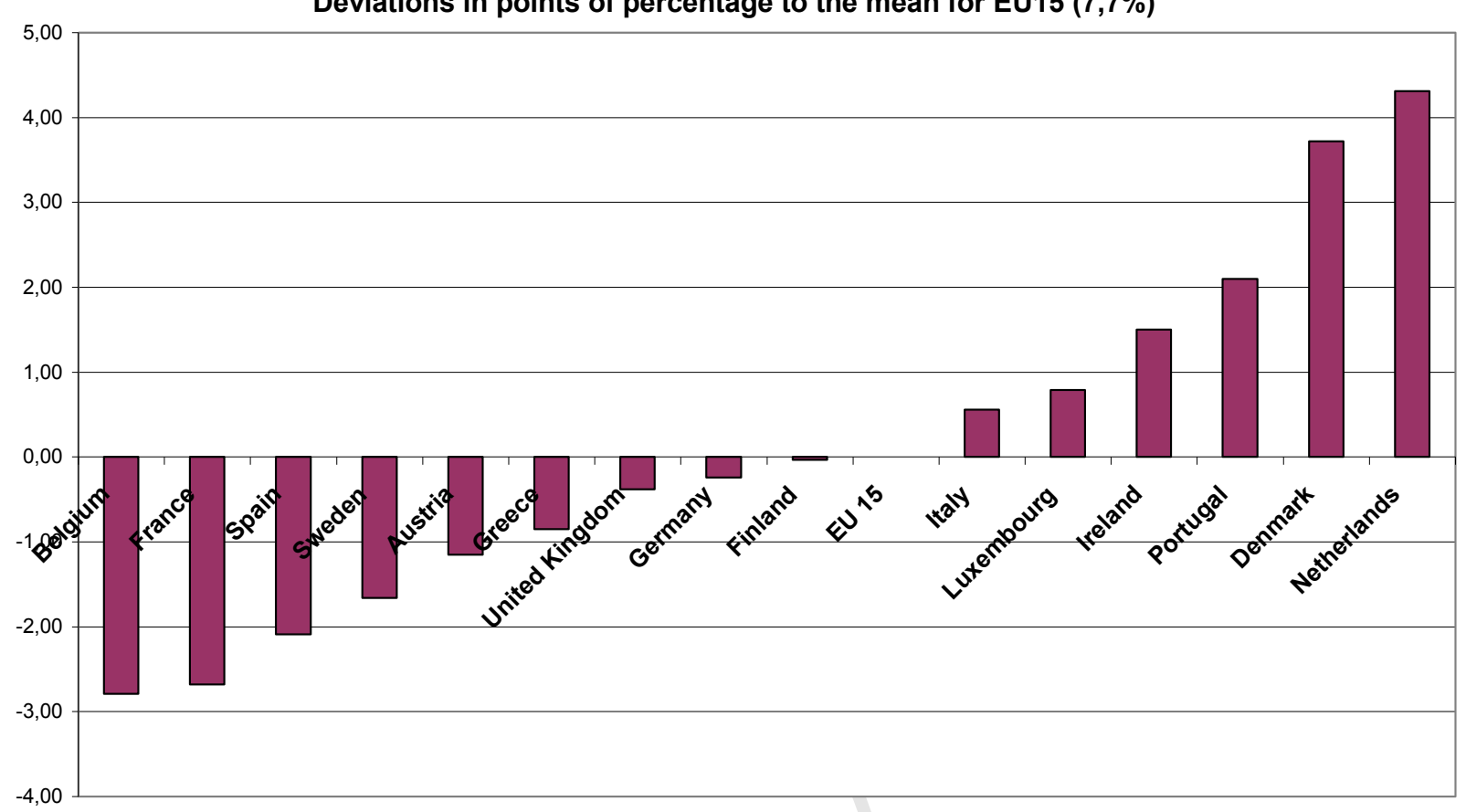

Source : OECD (2008) Revenue Statistics 1965-2007

As we have pointed out in the last section concerning the theoretical acceptability of the tax policy by heterogeneous agents, the results depend on the initial progressivity characteristics of the labor tax rate; this kind of policy mix will be more effective when the initial tax system is not so much progressive. On the basis of OECD publications (OECD, 2009), we use the mean wage tax rate (Income tax plus employee contributions less cash benefits as a \% of gross wage earnings) to compute a progressivity index of the European tax systems: this is the ratio between the wage tax rate observed at $167 \%$ and at $67 \%$ of median wages. Because we wish to set the family policy considerations aside, we focus on the tax rates bearing on single persons without children. As it is showed by Figure 4, Germany, France and Sweden typify the less progressive tax structure: their progressivity index are respectively 1.2, 1.3 and 1.6 which means that, for Germany for example, the mean tax rate at $167 \%$ of median wages is $20 \%$ greater than at $67 \%$ of median wages, since the difference of wages equals $250 \%$. These countries could therefore benefit in a similar manner from a policy mix bearing on a large increase of progressivity index 
allowing a significant decrease in the flat component of the income tax rate.

Figure 4

Tax Progressivity

Income tax plus employee contributions less cash benefits as a \% of gross wage earnings Single persons without children - by ranking order of progressivity index $(167 \% / 67 \%)$

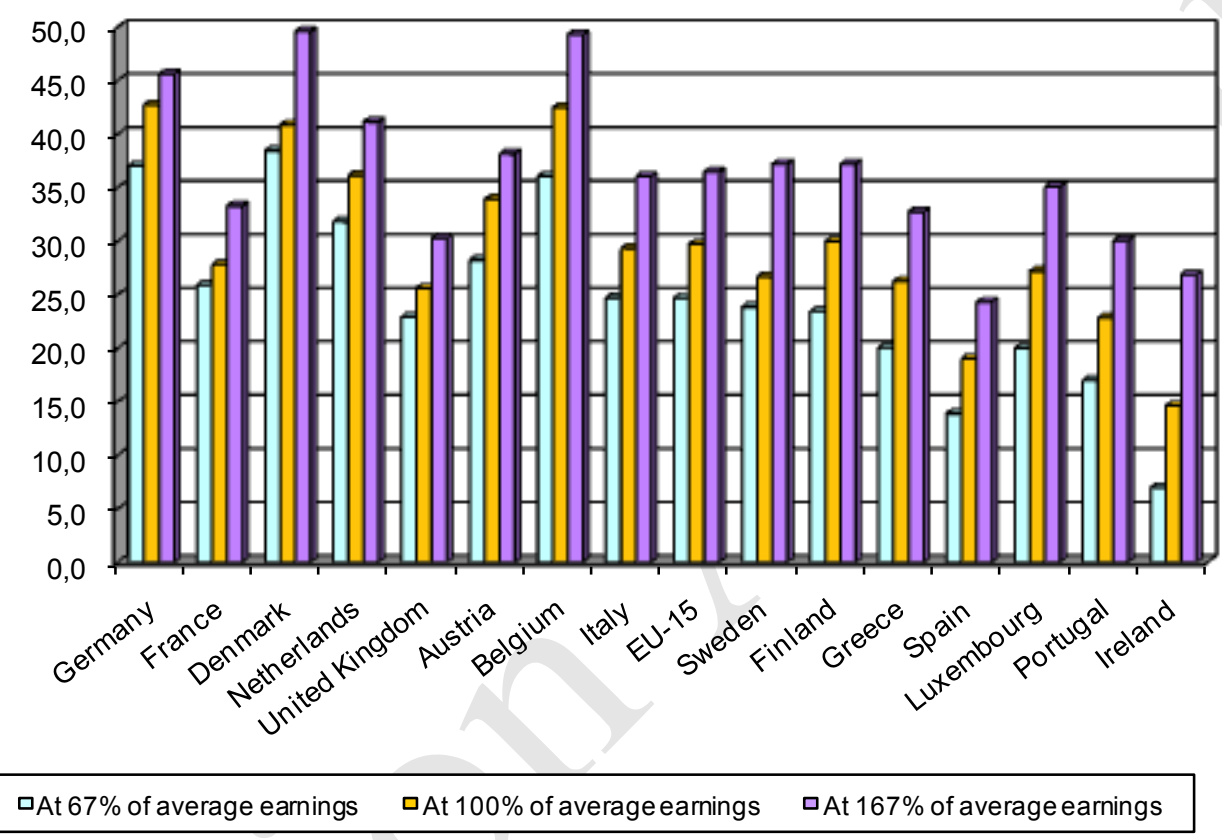

Source : OECD (2009) Taxing Wages 2008

\section{6 - Conclusion}

In September 2009, France, following Sweden and other Scandinavian countries, has officially proposed ${ }^{3}$ a carbon tax at a rate equal to $17 € /$ ton $\mathrm{CO}_{2}$. This could be a more general European movement towards a green tax reform. But, this goal is not easy to achieve. Indeed, the European countries are still heterogeneous, characterized by huge differences regarding long term energy

\footnotetext{
${ }^{3}$ The decision of the Conseil Constitutionnel of the 29th December 2009 requires some modifications of the perimeter of the taxed firms but it should not constitute a durable obstacle to the implementation of such a tax in France.
} 
solutions (like nuclear in France vs Germany), tax policy harmonization, coordination of public policies... The French debate is also still open. The intensive debates concern the recycling of the environmental tax revenues, showing at first a preference for compensating the short-term equity detrimental consequences instead of seeking to enhance the global efficiency, by paying lumpsum compensations rather than by reducing the labor taxes nor by re-designing the progressivity characteristics of the tax system. The need to also tax the firms which are already participating in the EU ETS will certainly make the compensation through labor tax cuts more appealing. All these debates also reflect the uncertainties around the short term consequences of the tax reform but, most of all, they express the reluctance of the societies regarding any green taxation reform. The latter should invite us to analyze more deeply the determinants of the individual environmental sensitivity, in order to better define the marketing of the future green policies. In this paper, we give the main conditions such that an environmental tax reform may achieve three goals: increase of the environmental quality, increase of the economic efficiency and improvement of the equity. The last point is an important one. The short-term costs of the reform are most important than the long-term consequences for the policy to be adopted. We show that the long term benefits could be compatible with the short term ones. These precise conditions have to be precisely evaluated for the European countries. 


\section{7 - References}

A.B. Atkinson, Social Justice and Public Policy, MIT Press (1983).

W.J. Baumol and W.E. Oates, "The Theory of Environmental Policy", Cambridge University Press, 2nd edition, (1988).

D.E. Bloom, D. Canning and J. Sevilla, The Effects of Health on Economic Growth: A Production Function Approach, World Development, 32, 1-13 (2004).

F. Bosello, C. Carraro and M. Galeotti, The Double Dividend Issue: Modelling Strategies and Empirical Findings, Environment and Development Economics, 6 (1), 9-45 (2001).

F. Bosello, R. Roson and R.S.J. Tol, Economy-wide Estimates of the Implications of Climate Change: Human Health, Ecological Economics, 58, 579-581 (2006).

A.L. Bovenberg, Green Tax Reforms and the Double Dividend: an Updated Reader's Guide, International Tax and Public Finance, 6, 421-444 (1999).

A.L. Bovenberg and B.J. Heidjra, Environmental Tax Policy and Intergenerational Distribution, Journal of Public Economics, 67, 1-24 (1998).

A.L. Bovenberg and R.A. de Mooij, Environmental Levies and Distortionary Taxation, American Economic Review, 84 (4), 1085-1089 (1994).

A.L. Bovenberg and R.A. de Mooij, Environmental Taxes and Labor-Market Distortions, European Journal of Political Economy, 10, 655-683 (1994).

A.L. Bovenberg and F. van der Ploeg, Optimal Taxation, Public Goods and Environmental Policy with Involuntary Unemployment, Journal of Public Economics, 62, 52-83 (1996).

European Commission, Environment and Employment: Building a Sustainable Europe, Brussels: EC, DG XI, (1998).

H.-P. Chao and S. Peck, Greenhouse Gas Abatement: How Much? and Who Pays?, Resource and Energy Economics, 22, 1-20 (2000).

M. Chiroleu-Assouline and M. Fodha, Double Dividend with Involuntary Unemployment: Efficiency and Intergenerational Equity, Environmental and Resource Economics, 31(4), 389-403 (2005).

M. Chiroleu-Assouline and M. Fodha, Double Dividend Hypothesis, Golden Rule and Welfare Distribution, Journal of Environmental Economics and Management, 51(3), 323-335 (2006).

M. Chiroleu-Assouline and M. Fodha, Environmental Tax and the Distribution of Income among Heterogeneous Workers, 18th Annual Conference of the European Association of Environmental and Ressource Economics, Amsterdam, 24-27 juin 2009.

P. Ekins, On the Dividends from Environmental Taxation, in T. O'Riordan, ed., Ecotaxation. Earthscan Publications, (1995).

R. Fiorito and F. Padrini, Distortionary Taxation and Labour Market Performance. Oxford Bulletin of Economics and Statistics, 63(2), 173-196 (2001).

O.N.E. Fisher and C. van Marrewijk, Pollution and Economic Growth, Journal of International Trade and Economic Development, 67 (1), 55-69 (1998). 
L.H. Goulder, Environmental Taxation and the "Double Dividend": A Reader's Guide, International Tax and Public Finance, 2, 157-183 (1995).

L.H. Goulder and R.N. Stavins, An eye on the future, Nature, 419, october, pp. 673-674 (2002).

A. Hansson, Taxpayers' Responsiveness to Tax Rate Changes and Implications for the Cost of Taxation in Sweden. International Tax and Public Finance, 14(5), 563-582 (2007).

M. Hübler, G. Klepper and S. Peterson, Costs of Climate Change - The Effects of Rising Temperatures on Health and Productivity, Ecological Economics, 68, 381-393 (2008).

A. John and R. Pecchenino, An Overlapping Generations Model of Growth and the Environment, The Economic Journal, 104, 1393-1410 (1994).

J.E. Ligthart, The Macroeconomic Effects of Environmental Taxes : A Closer Look at the Feasibility of Win-Win Outcomes, Working Paper of the International Monetary Fund, Washington, (1998).

G.E. Metcalf, A Distributional Analysis of Green Tax Reforms, National Tax Journal, 52 (4), 655-682 (1999).

W.E. Oates, Pollution Charges As a Source of Public Revenues, Resources of the Future Discussion Paper, QE92-05, (1991).

OECD, Revenue Statistics 1965-2007 - 2008 Edition: Special feature: Taxing Power of Subcentral Governments, Paris (2008)

OECD, Costs of Inaction on Key Environmental Challenges, Paris, (2008).

OECD, Taxing Wages 2008, Paris, (2009).

B.D. Ostro, The Effects of Air Pollution on Work Loss and Morbidity, Journal of Environmental Economics and Management, 10, 371--382, (1983).

D.W. Pearce, The Role of Carbon Taxes in Adjusting To Global Warming, The Economic Journal, 101, 938-948 (1991).

T. Pervin, U.-G. Gerdtham and C.Hampus Lytkens, Societal Costs of Air Pollution-Related Health Hazards: A Review of Methods and Results, Cost Effectiveness and Resource Allocation, 6 (19), (2008).

S. Proost and D. van Regemorter, The Double Dividend and the Role of Inequality Aversion and Macroeconomic Regimes, International Tax and Public Finance, 2, 207-219 (1995).

N. Ruiz and A. Trannoy, Le caractère régressif des taxes indirectes : les enseignements d'un modèle de microsimulation, Economie et Statistique, 413, 21-46 (2008).

E. Samakovlis, A. Huhtala, T. Bellander and M. Svartengren, Valuing Health Effects of Air Pollution - Focus on Concentration-response Functions, Journal of Urban Economics, 58, 230249 (2005).

A. Scott, Optimal Taxation and OECD Labor Taxes. Journal of Monetary Economics, 54(3), 925-944 (2007).

D. Terkla, The Efficiency Value of Effluent Tax Revenues, Journal of Environmental Economics and Management, 11, 107-123 (1984). 
R.C. Williams III, Environmental Tax Interactions when Pollution Affects Health or Productivity, Journal of Environmental Economics and Management, 44, 261-270 (2002).

R.C. Williams III, Health Effects and Optimal Environmental Taxes, Journal of Public Economics, 87(2), 323-335 (2003). 